\title{
Study of variability and heritability in coriander (Coriandrumsativum L.) genotypes under normal and limited moisture stress condition
}

A Singh, D Singh, VP Agrawal \& Dayanand

Journal of Agriculture and Ecology

\section{Journal of Agriculture} and Ecology

ISSN: 2456-9410

Volume: 5

Journal of Agriculture and Ecology (2018) 5: 50-55 http://doi.org/10.53911/JAE.2018.5105 


\title{
Study of variability and heritability in coriander (Coriandrumsativum L.) genotypes under normal and limited moisture stress condition
}

\author{
A Singh $^{1} \square$, D Singh $^{1}$, VP Agrawal $^{2} \&$ Dayanand $^{3}$ \\ ${ }^{1}$ S.K.N.Agriculture University Jobner-303329, India. \\ ${ }^{2}$ Plant biotechnology Centre, S.K.R.A.U.Bikaner-334006, India \\ ${ }^{3}$ K.V.K. Abusar, Jhunjhunu-333001, India \\ X Corresponding author: A Singh, E-mail: arvindfageria84@gmail.com
}

\begin{tabular}{|c|c|}
\hline Article Info & Abstract \\
\hline $\begin{array}{l}\text { Article history } \\
\text { Received: } 21 \text { May } 2018 \\
\text { Accepted: } 30 \text { May } 2018 \\
\text { Available online: } 15 \text { June } 2018 \\
\end{array}$ & $\begin{array}{l}\text { Drought is very common adverse environmental factor limiting } \\
\text { crop production in most of the tropical and subtropical regions of } \\
\text { India, thus limiting up productivity. Limited moisture stress is the } \\
\text { major constraint in productivity. To generate information on the }\end{array}$ \\
\hline $\begin{array}{l}\text { Key Words: Variability, } \\
\text { Coefficient of variations, } \\
\text { heritability, genetic advance, } \\
\text { limited moisture stress, biological } \\
\text { yield. }\end{array}$ & $\begin{array}{l}\text { effect of moisture stress on various traits which contribute for } \\
\text { yield would be helpful in developing tolerant coriander genotypes. } \\
\text { The result revealed that plant height; umbels per plant and } \\
\text { biological yield per ten plants are most important yield component } \\
\text { character in limited moisture condition. }\end{array}$ \\
\hline
\end{tabular}

Copyright $\odot 2018$ Singh et al., This is an open access article published under the terms of the Creative Commons Attribution License, which permits unrestricted use, distribution, and reproduction in any medium, provided the original work is properly cited.

Preferred citation: Singh A, Singh D, Agrawal VP \& Dayanand. 2018. Study of variability and heritability in coriander (Coriandrumsativum L., 2n=22) genotypes under normal and limited moisture stress condition. Journal of Agriculture and Ecology, 5: 50-55; http://doi.org/10.53911/JAE.2018.5105.

\section{Introduction}

Coriander (Coriandrum sativum L., $2 n=22)$ is an important seed spice crop belonging to family Apiaceae and is highly cross-pollinated. It is probably one of the earliest seed spices known to mankind (Pruthi 1976). The major problems in coriander breeding are limited genetic variability for yield and related characters and nonavailability of resistance against stem gall, powdery mildew and wilt. Coriander is cultivated in two specific agro-ecological conditions viz., irrigated and rainfed. In the areas where the crop is cultivated rainfed, erratic rainfall causes severe moisture stress conditions are faced, thus the productivity, as a consequence is less. In India, majority of the crop is still depended on rainfall and conserved moisture. Drought is a very common adverse environmental factor limiting crop production in most of the tropical and subtropical regions of India, thus limiting up productivity (Muthusamy et al. 2017; Samadia \& Haldhar 2017). Collection and evaluation of germplasm having adequate variability and study of genetic variability, heritability and genetic advance for economically important characters is the first essential requirement of successful breeding programme for selection of superior genotypes and improvement of any traits. Moreover, knowledge of heritability is essential for selection-based improvement as it indicates the extent of transmissibility of a character in 
future generations (Verma et al. 2015; Singh et al. 2016). Hence, the present study was, taken up to study variability, heritability and genetic advance among genotypes of coriander under normal and limited moisture condition.

\section{Materials and Methods}

The present investigation was carried out at Research Farm S.K.N. College of Agriculture, Jobner with 20 elite genotypes of coriander which were randomly selected from the germplasm collection of AICRP on Spices located at S.K.N. College of Agriculture, Jobner. The experimental material was evaluated in Randomized Block Design with three replications in two environments namely, (i) normal and (ii) limited moisture condition. In normal condition all the standard Horticultural practice were followed to raise the good and healthy crop in normal environment. Whereas in limited moisture condition oneirrigation was given at the time of sowing and one light irrigation after 8 days was given to ensure proper germination. After that no irrigations were given. In each environment/replication, each genotype was sown in a plot size of $2.0 \times 0.9 \mathrm{~m}^{2}$ consisting of three rows. The row to row and plant to plant distance was $30 \mathrm{~cm}$ and $10 \mathrm{~cm}$, respectively. Observations were recorded on ten characters viz., Days to 50 per cent flowering, plant height $(\mathrm{cm})$, branches per plant, umbels per plant, umbellates per umbel, seeds per umbel, 1000-seed weight (g), biological yield per ten plants $(\mathrm{g})$, volatile oil content $(\%)$ and seed yield per ten plants $(\mathrm{g})$ in each entry and in each replication in both the two sowing conditions. The data obtained in this study were subjected to appropriate statistical analysis. Pooled analysis of variance was carried out to know the genotype $\mathrm{x}$ environment interaction. The expected genetic advance for each character was calculated according to the formulae suggested by Johnson et al. (1955).

\section{Results and Discussion}

The analysis of variance revealed that significant variability was present in the genotypes for most of the characters under normal and limited moisture condition. This suggested that the material had adequate variability and response to selection may be accepted in the breeding programme for seed yield or any of its supporting characters (Table $1,2 \& 3)$. These results are in agreement with the findings of Mathur et al. (1971) in coriander in normal and moisture stress conditions. The replication mean square were also significant for the characters viz., umbels per plant, umbellates per umbel, 1000-seed weight and volatile oil content in normal condition and umbels per plant, umbellates per umbel, 1000-seed weight, volatile oil content and biological yield in limited moisture condition indicating their sensitivity to the environment. Changes in the means of character in limited moisture condition in comparison to normal condition were noted. Mean values were higher in normal condition in comparison to limited moisture condition for the characters viz., plant height, seeds per umbel, 1000-seed weight, biological yield and seed yield per plant. Volatile oil content had higher mean value in limited moisture condition in comparison to normal condition. This indicated clearly the adverse effect of 
moisture stress on the character expression by the genotypes. The mean values of character days to $50 \%$ flowering, branches per plant, umbels per plant, umbellates per umbel and volatile oil content varied little across environmental conditions.

The estimates of coefficients of variations were in general higher in stress environment than in normal. In both environment high estimates of variation were observed for traits $v i z$., days to $50 \%$ flowering, plant height, branches per plant, umbels per plant, seeds per umbel, 1000-seed weight, volatile oil content and seed yield, thus selection may be more effective for these characters because the response to selection is

Table 1. Pooled ANOVA for different characters of coriander genotype evaluated under normal $\left(\mathrm{C}_{1}\right)$ and limited moisture $\left(\mathrm{C}_{2}\right)$ conditions

\begin{tabular}{|c|c|c|c|c|c|c|}
\hline \multirow{2}{*}{$\begin{array}{l}\text { S. } \\
\text { No. }\end{array}$} & \multirow[t]{2}{*}{ Characters } & \multicolumn{5}{|c|}{ Source of variation with d.f. } \\
\hline & & $\begin{array}{l}\mathrm{E} \\
1 \\
\end{array}$ & $\begin{array}{l}\mathrm{R} \\
4 \\
\end{array}$ & $\begin{array}{l}\mathrm{G} \\
19 \\
\end{array}$ & $\begin{array}{c}\mathrm{E} \times \mathrm{G} \\
19 \\
\end{array}$ & $\begin{array}{c}\text { Error } \\
76\end{array}$ \\
\hline 1. & $\begin{array}{l}\text { Days to } 50 \% \\
\text { flowering }\end{array}$ & $598.53 * *$ & 11.01 & $556.78 * *$ & 18.71 & 11.77 \\
\hline 2. & Plant height $(\mathrm{cm})$ & $4575.67 * *$ & 9.67 & $13.74 * *$ & 48.76 & 26.18 \\
\hline 3. & Branches per plant & 6.67 & 0.24 & 6.03 & 0.17 & 0.24 \\
\hline 4. & Umbels per plant & $408.85^{* *}$ & 55.70 & 22.47 & 6.32 & 7.17 \\
\hline 5. & Umbellets per umbel & 32.67 & 1.31 & 0.86 & 0.13 & 0.14 \\
\hline 6. & Seeds per umbel & $1668.80 * *$ & 11.32 & $225.32 * *$ & 45.34 & 16.78 \\
\hline 7. & $\begin{array}{l}\text { 1000-seed weight } \\
(\mathrm{g})\end{array}$ & 103.73 & 0.89 & 23.80 & 4.59 & 0.14 \\
\hline 8. & $\begin{array}{l}\text { Volatile oil content } \\
(\%)\end{array}$ & 0.04 & 0.00 & 0.02 & 0.01 & 0.00 \\
\hline 9. & Biological yield (g) & $10982.53 * *$ & $215.53 * *$ & $1165.74 * *$ & $448.04 * *$ & 94.34 \\
\hline 10. & Seed yield (g) & $2726.53 * *$ & 27.17 & $200.19 * *$ & $81.62 * *$ & 32.02 \\
\hline
\end{tabular}

$*$ and $* *$ refers to significant at $\mathrm{P}=0.05$ and $\mathrm{P}=0.01$, respectively 
Table 2. Mean, range, coefficients of variation, heritability (broad sense) and genetic advance for yield and other attributes (normal condition)

\begin{tabular}{|c|c|c|c|c|c|c|c|c|}
\hline \multirow{2}{*}{$\begin{array}{l}\text { S. } \\
\text { No. }\end{array}$} & \multirow[t]{2}{*}{ Characters } & \multirow[t]{2}{*}{ Mean } & \multirow[t]{2}{*}{ Range } & \multicolumn{3}{|c|}{ Coefficients of variation } & \multirow{2}{*}{$\begin{array}{l}\text { Heritability } \\
\% \text { (bs) }\end{array}$} & \multirow{2}{*}{$\begin{array}{l}\text { GA as \%age } \\
\text { of mean }\end{array}$} \\
\hline & & & & Environment & Genotypic & Phenotypic & & \\
\hline 1. & $\begin{array}{l}\text { Days to } 50 \% \\
\text { flowering }\end{array}$ & 68.70 & $54.00-88.00$ & 4.70 & 14.36 & 15.10 & 90.33 & 28.11 \\
\hline 2. & Plant height (cm) & 59.99 & $51.43-67.20$ & 8.68 & 5.62 & 10.34 & 29.58 & 6.30 \\
\hline 3. & Branches per plant & 6.27 & $4.43-8.43$ & 7.97 & 15.49 & 17.42 & 79.08 & 28.38 \\
\hline 4. & Umbels per plant & 18.14 & $14.20-24.47$ & 16.16 & 8.53 & 18.37 & 22.59 & 8.55 \\
\hline 5. & $\begin{array}{l}\text { Umbellates per } \\
\text { umbel }\end{array}$ & 5.47 & $4.60-6.10$ & 8.15 & 4.96 & 9.54 & 27.05 & 5.31 \\
\hline 6. & Seeds per umbel & 39.37 & $27.63-52.53$ & 10.26 & 15.29 & 18.42 & 68.97 & 26.17 \\
\hline 7. & $\begin{array}{l}\text { 1000-seed weight } \\
\text { (g) }\end{array}$ & 13.59 & $9.22-17.52$ & 3.24 & 17.32 & 17.62 & 96.61 & 35.07 \\
\hline 8. & $\begin{array}{l}\text { Volatile oil content } \\
(\%)\end{array}$ & 0.29 & $0.17-0.42$ & 9.078 & 18.97 & 21.03 & 81.37 & 35.25 \\
\hline 9. & Biological yield (g) & 89.28 & $\begin{array}{l}60.00- \\
122.67\end{array}$ & 11.74 & 17.85 & 21.36 & 69.81 & 30.72 \\
\hline 10. & Seed yield $(\mathrm{g})$ & 41.32 & $29.00-56.67$ & 14.75 & 15.83 & 21.64 & 53.53 & 23.86 \\
\hline
\end{tabular}

Table 3. Mean, range, coefficients of variation, heritability (broad sense) and genetic advance for yield and other attributes (limited moisture condition)

\begin{tabular}{|c|c|c|c|c|c|c|c|c|}
\hline \multirow{2}{*}{$\begin{array}{l}\text { S. } \\
\text { No. }\end{array}$} & \multirow[t]{2}{*}{ Characters } & \multirow[t]{2}{*}{ Mean } & \multirow[t]{2}{*}{ Range } & \multicolumn{3}{|c|}{ Coefficients of variation } & \multirow{2}{*}{$\begin{array}{l}\text { Heritabilit } \\
\text { y \% (bs) }\end{array}$} & \multirow{2}{*}{$\begin{array}{l}\mathrm{GA} \text { as \%age } \\
\text { of mean }\end{array}$} \\
\hline & & & & Environment & $\begin{array}{l}\text { Genotyp } \\
\text { ic }\end{array}$ & Phenotypic & & \\
\hline 1. & $\begin{array}{l}\text { Days to } 50 \% \\
\text { flowering }\end{array}$ & 73.17 & $56.00-90.67$ & 4.96 & 12.73 & 13.66 & 86.85 & 24.43 \\
\hline 2. & Plant height $(\mathrm{cm})$ & 47.64 & $32.20-56.23$ & 10.55 & 11.24 & 15.42 & 53.14 & 16.88 \\
\hline 3. & $\begin{array}{l}\text { Branches per } \\
\text { plant }\end{array}$ & 5.80 & $3.97-7.73$ & 8.41 & 16.90 & 18.88 & 80.15 & 31.18 \\
\hline 4. & Umbels per plant & 14.45 & $9.87-17.37$ & 16.58 & 10.51 & 19.63 & 28.69 & 11.60 \\
\hline 5. & $\begin{array}{l}\text { Umbellates per } \\
\text { umbel }\end{array}$ & 4.43 & $3.73-5.20$ & 6.82 & 9.04 & 11.32 & 63.77 & 14.87 \\
\hline 6. & Seeds per umbel & 31.91 & $18.77-44.50$ & 13.01 & 20.50 & 24.28 & 71.28 & 35.66 \\
\hline 7. & $\begin{array}{l}\text { 1000-seed weight } \\
(\mathrm{g})\end{array}$ & 11.43 & $8.68-16.67$ & 2.75 & 17.63 & 17.85 & 97.63 & 4.10 \\
\hline 8. & $\begin{array}{ll}\text { Volatile } & \text { oil } \\
\text { content }(\%) & \end{array}$ & 0.33 & $0.23-0.48$ & 7.77 & 20.42 & 21.85 & 87.34 & 39.31 \\
\hline 9. & $\begin{array}{l}\text { Biological yield } \\
(\mathrm{g})\end{array}$ & 70.15 & $29.33-106.67$ & 12.66 & 21.19 & 24.69 & 73.71 & 37.48 \\
\hline 10. & Seed yield $(\mathrm{g})$ & 31.78 & $15.00-41.67$ & 16.32 & 17.19 & 23.69 & 52.55 & 25.64 \\
\hline
\end{tabular}

considerably difficult or virtually impractical

If heritability of a character is high (> $60 \%$ ), selection for such a charactersbecomes fairly easy. This is because there would be close correspondence between genotypic and phenotypic variation due to a relatively smaller contribution of environment to the phenotype, but for a character with a low heritability $(<40 \%)$, selection may be due to masking effect of environment on the genotypic effect.In present investigation broad sense heritability was observed to be high for days to $50 \%$ flowering, branches per plant, seeds per umbel, 1000-seed weight, volatile oil content and biological yield in normal and for most of the characters except plant height, seed yield and umbels per plant in limited 
moisture condition, which is in agreement with earlier reports of Patel \& Agalodia (2007) for umbels per plant, 1000-seed weight and essential oil in coriander. While the estimates of heritability changed very little between the environments for traits -branches per plant, 1000-seed weight, biological yield and seed yield. The change was considerable for plant height and umbellates per umbel. The estimates were higher in the stress environment.Heritability estimates alone do not provide information on the amount of genetic progress that would result from the selection of the best genotype. Therefore, genetic advance as percentage of mean was calculated in order to determine the relative merits of different characters that can be further utilized in the selection programme.

In normal condition high magnitude of genetic advance as percentage of mean was obtained for 1000-seed weight, volatile oil content and biological yield which is in agreement with earlier reports of Patel \& Agalodia (2007) for volatile oil content and 1000 -seed weight in coriander. Moderate genetic advance as percentage of mean was observed for days to $50 \%$ flowering, branches per plant, seeds per umbel and seed yield per plant which is in agreement with the reports of Bhandari \& Gupta (1991) for seeds per umbel in coriander. Low magnitude genetic advance as percentage of was observed for plant height, umbels per plant and umbellates per umbel. These results are in accordance with the earlier report of Jain et al. (2002) in coriander. In normal condition, 1000 seed weight, volatile oil content and biological yield had high heritability along with high genetic advance as percentage of
mean.Whereas, in limited moisture condition character viz,volatile oil content, biological yield, seeds per umbel and branches per plant had high heritability along with high genetic advance as percentage of mean which indicated that these characters are governed by additive gene action and selection of these characters would be effective. The character days to $50 \%$ flowering had high heritability with moderate genetic advance as percentage of mean. Comparison of the genetic advance estimates between the environments indicated that minimum changes in the estimates were observed for traits- branches per plant and seed yield. While the changes were considerable for traits-plant height, umbellates per umbel, seeds per umbel, 1000-seed weight and biological yield while in traits plant height, umbellates per umbel, seeds per umbel and biological yield, the estimates increased in stress in comparison to normal environment. The estimate was lower in 1000-seed weight in stress in comparison to normal environment. Seed yield per plant had moderate heritability and genetic advance as percentage of mean. Plant height, umbellets per umbel and 1000-seed weight had high heritability and low genetic advance as percentage of mean. Umbels per plant had low heritability with low genetic advance as percentage of mean. This indicates the influence of non-additive gene action and considerable influence of environment on the expression of these traits. These traits could be exploited through manifestation of dominance and epistatic components through heterosis breeding. Hence, the breeder should adopt suitable breeding methodology to utilize both additive and non-additive gene effects 
simultaneously (Verma et al., 2015). Since yield is a multiplicative character dependent on its component characters, direct selection for yield may not be that effective as the one based on its component characters. In the present investigation,biological yield had high estimates of PCV, GCV, heritability and genetic advance as percentage of mean in both environments. Hence, it is suggested that major emphasis should be given on such characters for further improvement.

\section{References}

Bhandari MM \& Gupta A. 1991. Variation and association analysis in coriander. Euphytica, 58: 1-4.

Jain UK, Singh D \& Jain SK. 2002. Assessment of genetic variability in coriander. Annals of Plant Soil Research, 4: 329-330.

Johnson HW, Robinson HF \& Comstock, RE. 1955. Estimates of genetic and environmental variability in soybean. Agronomy Journal, 47, 314-318.

Mathur SC, Anwar M \& Bhargava PD. 1971. Studies on splitting of phenotypic and genotypic complexes and their correlation in coriander (Coriandrum sativum L.). Rajasthan Journal of Agricultural Science, 2: 63-71.
Muthusamy SK, Sivalingam PN, Sridhar J, Singh D \& Haldhar SM. 2017. Biotic stress inducible promoters in crop plants-a review. Journal of Agriculture and Ecology, 4: 14-24.

Patel VR \& Agalodia AV. 2007. Genetic variability studies in coriander (Coriandrum sativum L.). Published in National Seminar on Production, Development, Quality and Exports of Seed spice-Issues and Strategies held at National Research Centre on Seed Spices, Tabaji, Ajmer, Rajasthan, p 16.

Pruthi JS. 1976. Spices and Condiments: Chemistry, Microbiology and Technology. New York, Academic Press, pp. 1-6.

Samadia DK \& Haldhar SM. 2017. Breeding strategies and scope of improvement in arid zone fruit crop-plants under abiotic stressed agro-climate: an analysis. Journal of Agriculture and Ecology, 4: 1-13.

Singh H, Swaminathan R \& Haldhar SM. 2016. Foraging behavior of insect pollinators on coriander. Indian Journal of Arid Horticulture, 11:74-80.

Verma AK, Uma Jyothi K \& Rao AVD. 2015. Variability and character association studies in dolichos bean (Lablab purpureus L.) genotypes. Indian Journal of Agricultural Research, 49 (1): 46-52. 